\title{
THE GREEN REVOLUTION AND CROPPING INTENSIT'Y
}

\author{
M.D. Hoskins*
}

This paper discusses some of the difficulties associated with increasing cropping intensity in developing agriculture. Although it is concerned with the problem as observed in the Kosi area of North Bihar, India, many of the issues are probably relevant in a large number of other regions as well. ${ }^{1}$

The Kosi area was traditionally very poor. It was subjected to regular flooding as the river Kosi moved about. 70 miles west in a period of 200 years. Many schemes to contain this movement were brought to fruition in the 1950's, and subsequent flood control measures were supplemented by a canal irrigation system which began operation in the mid 1960's. This coincided with the developments which have come to be referred to as the 'Green Revolution'. The principal object of these measures was to raise agricultural output by expanding cultivated acreage and raising yields.

Although irrigation and flood control can raise yields of traditional crop varieties by stabilizing them in the higher range of their yields, the main hope for improvement lies in the introduction of new fertilizer-responsive varieties. Extension of cultivated acreage can be achieved by several kinds of measures: by land levelling and drainage, which bring water-logged land into cultivation; by providing irrigation and raising soil fertility, which bring poor quality, higher elevation, dry land into cultivation; and by more intensive cultivation.

In the Kosi region there are three seasons - Kharif, Rabi and Summer. Kharif is the main monsoon paddy season around which the agricultural system revolves. Rabi is the winter season in which wheat, pulses and oilseeds are grown; it is becoming increasingly important as new wheat varieties become

\footnotetext{
* Martin Hoskins was formerly a Research Officer at IDS, 1968-71. He is currently Research Fellow in the Economics Dept., University of Leicester.
}

1 For a more detailed discussion of the development problems of the Kosi area, see M.D. Hoskins, "The Kosi Project", IDS Bulletin, July 1970. 
established and irrigation spreads. The Summer season is hot and dry, but jute, Bhadai paddy and maize are grown and with the extension of irrigation, it is potentially quite an important season. With assured irrigation, land which was cultivated only once with Kharif paddy can conceivably be sown 3 times a year, or at least 5 times in 2 years.

While extension of cultivable land will probably be the main means of increasing cropped area, this will become more difficult. It is also not a likcly strategy for the approximately $55 \%$ of cultivating households who cultivate holdings of 5 acres or less: for these, intensification is far more important. Intensive cropping is also an attractive method of maximizing the return from fixed tube-well borings, on which more reliance for the expansion of irrigation is now being placed. These provide water all the year to plots which are of somewhat higher elevation where there is no water-logging problem, so that it is extremely profitable to concentrate resources on the multiple cropping of the smaller areas surrounding tube-wells. Multiple cropping is difficult however, because the growth characteristics of crops in the area leave very short intervals between the harvest of one crop and the sowing or transplanting of the next. In some cases there is no interval at all and in others the interval is so short that there is an extremely peaked demand for ploughing inputs; this makes multiple cropping on large areas very difficult. Really intensive cultivation is impossible with traditional crop varieties, which permit two major crops per year at most. (Some crops can be sown while others are still standing, but these are relatively unimportant). The new crop varieties are developed not only to be more responsive to fertilizer but also to have shorter growing periods, and flowering times less sensitive to day length. This enables them to be multiple cropped far more easily, for not only is there more time between crops, but their sowing times should be more flexible. While new wheat has become established - even if not giving as large returns as originally anticipated - new paddy varieties have not yet proved successful, though it is fairly certain that once their pest resistance has been improved and they have been bred specifically for Indian conditions, they will be cultivable in both Summer and Kharif seasons.

There are real questions, however, as to just how difficult it is to practise multiple cropping with traditional varieties, just how different the new varieties are and just how much easier it will 
TABLE 1: Cultivation data for crops in River Kosi region, 1970.

\begin{tabular}{|c|c|c|c|c|c|}
\hline Crop & Variety & Variable & Mean & $\begin{array}{l}\text { Variance } \\
\text { (in days) }\end{array}$ & $\begin{array}{l}\text { Number of } \\
\text { observations }\end{array}$ \\
\hline \multirow{2}{*}{$\begin{array}{c}\text { Summer } \\
\text { paddy }\end{array}$} & local & harvest date & Aug. 7 & 890 & 9 \\
\hline & High yield & harvest date & July 23 & 120 & 8 \\
\hline \multirow[t]{2}{*}{$\begin{array}{l}\text { Kharif } \\
\text { paddy }\end{array}$} & local & $\begin{array}{l}\text { transplant } \\
\text { date } \\
\text { duration of } \\
\text { cultivation } \\
\text { harvest date }\end{array}$ & $\begin{array}{l}\text { July } 20 \\
142 \text { days } \\
\text { Dec. } 4\end{array}$ & $\begin{array}{r}76 \\
360 \\
150\end{array}$ & $\begin{array}{l}57 \\
56 \\
57\end{array}$ \\
\hline & High vield & $\begin{array}{l}\text { transplant } \\
\text { date } \\
\text { duration of } \\
\text { cultivation } \\
\text { harvest date } \\
\end{array}$ & $\begin{array}{l}\text { July } 10 \\
110 \text { days } \\
\text { Oct. } 28\end{array}$ & $\begin{array}{r}69 \\
140 \\
230 \\
\end{array}$ & $\begin{array}{l}11 \\
10 \\
10 \\
\end{array}$ \\
\hline \multirow[t]{3}{*}{ Wheat } & Punjab & $\begin{array}{l}\text { sowing date } \\
\text { duration of } \\
\text { cultivation }\end{array}$ & $\begin{array}{l}\text { Nov. } 9 \\
143 \text { days }\end{array}$ & $\begin{array}{r}1100 \\
330\end{array}$ & $\begin{array}{l}10 \\
10\end{array}$ \\
\hline & $\begin{array}{l}\text { Punjab and } \\
\text { local }\end{array}$ & $\begin{array}{l}\text { sowing date } \\
\text { duration of } \\
\text { cultivation } \\
\text { harvest date }\end{array}$ & $\begin{array}{l}\text { Nov. } 20 \\
134 \\
\text { April } 2\end{array}$ & $\begin{array}{r}1000 \\
720 \\
16\end{array}$ & $\begin{array}{l}24 \\
24 \\
24\end{array}$ \\
\hline & High vield & $\begin{array}{l}\text { sowing date } \\
\text { duration of } \\
\text { cultivation } \\
\text { harvest date }\end{array}$ & $\begin{array}{l}\text { Nov. } 22 \\
130 \\
\text { April } 2\end{array}$ & $\begin{array}{r}540 \\
440 \\
18\end{array}$ & $\begin{array}{l}28 \\
27 \\
10\end{array}$ \\
\hline Jute & $\begin{array}{l}\text { all } \\
\text { varieties }\end{array}$ & $\begin{array}{l}\text { sowing date } \\
\text { duration of } \\
\text { cultivation } \\
\text { harvest date }\end{array}$ & $\begin{array}{l}\text { April } 7 \\
133 \text { days } \\
\text { Aug. } 18\end{array}$ & $\begin{array}{l}1300 \\
1500 \\
1000\end{array}$ & $\begin{array}{l}16 \\
16\end{array}$ \\
\hline
\end{tabular}


be to practise multiple cropping once they are introduced. We attempt to throw some light on these problems by considering the harvesting and sowing or transplanting dates of the main crops in Kosi - Summer paddy, Kharif paddy, wheat, and jute - as revealed by a survey conducted there. This survey is not entirely reliable but it does provide some insight into the problem. Although the actual varieties of high-yielding (H.Y.) paddy considered here are no longer grown, their sowing and harvesting dates are taken as indicative of what is likely to be achieved and can be used to derive indications of what further improvements need to be achieved as regards shorter growing durations. The data on which the discussion rests is presented in Table 1 .

Standard statistical tests on the data in Table 1 reveal differences between the traditional and H.Y. varieties. The transplanting dates of local and H.Y. Kharif paddy are found to be significantly different, as well as their cultivation lengths and harvest dates. The H.Y. variety is transplanted earlier and this, together with its significantly shorter growing period, leads to a much earlier harvesting date. The variance of the transplanting date for H.Y. Kharif paddy is also found to be significantly lower than for local paddy. This is important since it suggests that the widespread cultivation of H.Y. paddy will increase the peakedness of demand for ploughing power to prepare land for transplanting, as well as the peakedness of demand for labour for transplanting.

Although there is found to be no significant difference between the sowing dates of local or Punjab wheat and the sowing date of H.Y. wheat, a significant difference is found in the variances of these sowing dates. ${ }^{2}$ The variance of sowing dates forH.Y. wheat is found to be significantly lower than for alternative varieties, once more

2 Although the difference of 13 days between the mean sowing dates of Punjab and H.Y. wheat may appear large, this in fact is not so when allowance is made for the very large variances of the sowing dates. It is consideration of such variances which necessitates statistical tests of significance. The sort of question we have to ask is: given so much variance in the sowing dates, can we be sure that there really is a difference in these two mean sowing dates? If we find there is no significant difference at, say, the $5 \%$ level, then we are implying that if we conducted such tests many times, using different but similar samples of sowing dates, then we could expect to be really correct in concluding that there is no difference 95 times out of 100 . 
suggesting that widespread adoption will lead to an increase in the peakedness of demand for ploughing power in land preparation for Rabi cultivation. Further analysis suggests that any increased acreage under wheat will be due to the higher yields of new wheat, and increased intensity of cultivation made possible by the short duration of new Kharif paddy rather than any shortening of the cultivation period of wheat.

The above discussion has suggested that there is an incentive to extended the areas cultivated by H.Y. varieties. But how much scope is there for increasing cropping intensity? Two types of tests were used to assess the feasibility of increased intensity, one for detecting significant differences in sowing and harvesting dates and the other for detecting significant differences after a seven-day interval has been allowed for land preparation between crops. This interval is considered to be the minimal consistent with acceptable land preparation; it permits two ploughings at two-day intervals together with a pre-sowing ploughing. The results of the full analysis cannot be given here, but some indication of the method can be made.

The harvest date of H.Y. Summer paddy is found to be not significantly different from the transplanting date of H.Y. Kharif paddy at the $2.5 \%$ levl, though an interval allowing 7 days for ploughing is found to be significantly different even at the $0.5 \%$ level. The early transplanting date of H.Y. Kharif paddy, together with the small variances in the harvest date of H.Y. Summer paddy and in the transplanting date of H.Y. Kharif paddy (See Tabel 1) make this a very difficult sequence to follow.

This is an important conclusion since these two crops are the ones on which the paddy part of the 'Green Revolution' depends. It suggests that two paddy crops can only be grown on the same piece of land with great difficulty, and especially so on large areas, where there will be a very peaked demand for ploughing power. The analysis suggests that research into the development of an earlier maturing Summer paddy and a later transplanted or more flexible and shorter duration Kharif paddy would be well worthwhile.

A general conclusion of the full analysis is that it is difficult to take two paddy crops per year on the same piece of land; the only way this can reasonably be achieved is with H.Y. Summer and local Kharif paddy, and even this will require changes in the mean transplanting dates of the two sorts of paddy. 
Analysis of all the various possible crop sequences suggests that the scope for increasing cropping intensity is limited. Whilst the introduction of short duration Summer paddy will permit cultivation of subsequent local kharif paddy it will not easily permit the possibility of cultivating wheat on the same land. Since local Summer paddy does not permit the cultivation of H.Y. Kharif paddy there is little possibility of growing food crops in three consecutive seasons on a plot. Similar remarks apply to jute, which, in its turn, precludes cultivation of H.Y. Kharif paddy which is the only Kharif paddy permitting wheat in the Rabi season.

It is difficult to see how three crops can be taken in one year or even five crops in two years with the existing growing times. It is clear, however, that shortening growing periods does increase the ease with which two crops can be taken. If cultivation times could be shortened still more and a H.Y. Kharif paddy with a later transplanting date developed, there is a very real possibility of taking three crops in a year. This should not be taken, however, to imply that three crops could be taken in a year for a series of years. Even with shorter duration crops than at present, it is likely that the third crop would be sown late. Summer cultivation would probably delay. transplantation of Kharif paddy and this would be reflected in the sowing date of wheat. On small areas this effect may not be great. If we accept that the time intervals between successive crops must be short if late sowing is to be avoided, however, potential ploughing constraints will restrict the areas cultivated intensively. Extension of intensively cropped areas under ploughing constraints will only be achieved by postponing the sowing and transplanting of succeeding crops, thus increasing the likelihood of the third crop of any year being sown late. With a one week interval between crops we could generate the sequence of activities on 1.2 acres of land comprising 3 plots each of 0.4 acres ploughable by a bullock pair in one day, as shown in Table 2.

A similar operation sequence would apply at the harvesting period of Kharif paddy and the sowing time of wheat. Even making the unrealistic assumption that a piece of land can be ploughed on the same day as it is harvested and needs only three ploughings after cultivation in the previous season, we see that draught power can easily become a problem. Extending the intensive acreage by a 
TABLE 2: Suggested operational sequence of activities on three 0.4 acre plots to extend intensively-cropped areas, under ploughing constraints

\begin{tabular}{|c|c|l|}
\hline Day & Plot & \multicolumn{1}{|c|}{ Activities } \\
\hline 1 & 1 & Harvest 0.4 acres Summer paddy; 1st ploughing for Kharif paddy \\
2 & 2 & Harvest 0.4 acres Summer paddy; 1st ploughing for Kharif paddy \\
3 & 3 & Harvest 0.4 acres Summer paddy; 1st ploughing for Kharif paddy \\
4 & 1 & 2nd ploughing for Kharif paddy \\
5 & 2 & 2nd ploughing for Kharif paddy \\
6 & 3 & 2nd ploughing for Kharif paddy \\
7 & 1 & 3rd ploughing and transplanting for Kharif paddy \\
8 & 2 & 3rd ploughing and transplanting for Kharif paddy \\
9 & 3 & 3rd ploughing and transplanting for Kharif paddy \\
\hline
\end{tabular}

further 1.2 acres would lead to the above sequence repeated over days 10 to 19 if only one pair of bullocks is available. This, of course, delays transplanting of the Kharif crop and this delay will be echoed in its harvesting, and hence in the sowing time of any succeeding wheat crop. This highlights the importance of draught power for intensive cultivation. This is particularly important with H.Y.

varieties, as we have seen, where the variance of transplanting and sowing dates is lower than for local varieties. If draught power is constraining it is possible that land will either be left fallow in the Kharif season or sown with local varieties which, in turn, will lead to land being left fallow in the next season - since the longer growing duration of local paddy precludes wheat cultivation.

Soil moisture limitations on unirrigated land will also limit intensity of cultivation, for all crops use soil moisture, leaving less for succeeding crops. Thus wheat will use soil moisture leaving less for Summer paddy, and Kharif paddy will leave less for wheat, though this may not be crucial, given the high monsoon rainfall. Similarly, wheat will deprive jute of moisture. Such factors will be unimportant on irrigated plots and we can expect intensive cultivation to be concentrated on these. This is even more likely to be the case, since the new varieties are dwarfs and can only be grown on land which does not suffer from excessive waterlogging. 
The overall conclusion is that we cannot really expect the new crop varieties to displace the traditional except in the case of wheat, where the growth characteristics are indistinguishable from older varieties and the yields higher. We could easily see a system developing where small areas, probably those irrigated by tube-wells, are cultivated intensively with H.Y. varieties, other areas are put under new crops which are sown too late to permit intensive cultivation but within the shorter time periods within which their yields are not significantly reduced, while other areas are still put under traditional varieties, which can be sown somewhat later. These last areas will also not be cultivated intensively since traditional varieties do not permit this.

The discussion here is not conclusive, however, and further analysis is needed to reveal just how many acres can be put under multiple cropping of different types with existing distributions of sowing and harvest dates. It will also be necessary to investigate the costs of increasing multiple cropping by providing more irrigated land and more ploughing power. 